\title{
IMPROVING THE STUDENTS' READING COMPREHENSION THROUGH KNOW-WANT-LEARN STRATEGY
}

\author{
Ariana \& Rahmawati Umar \\ English Education Department, Faculty of Teacher Training and Education \\ Muhammadiyah University of Makassar
}

\begin{abstract}
Improving The Students' Reading Comprehension through Know-Want-Learn Strategy at the first grade students of SMA Negeri 18 Makassar. The objective of this research was intended to explain the improvement of the students' interpretative and literal reading comprehension through Know-Want-Learn Strategy at the first grade students of SMA Negeri 18 Makassar especially in class X 3. The strategy of this research was a Classroom Action Research (CAR) consisted of two cycles, one cycle consisted of four meetings. It means that there were eight meetings for two cycles. This classroom action research was done at the first grade students of SMA Negeri 18 Makassar in Daya regency for English subject. As subject in this research was class X 3 in 2012-2013 academic year with students' number as about 32 students. Those consist of 22 women and 10 men. The instrument of this research were observation sheet and reading test or evaluation. The findings of the research were students achievement in reading comprehension was 54,07 in D-test, then Cycle I is 69,07 and it became 73,81 in Cycle II. The students activeness in learning reading comprehension in the first meeting of Cycle I was 45,39\% then it became 90,78\% in fourth meeting of Cycle II.
\end{abstract}

Keyword: Improving, reading, know, want, learn, strategy.

In learning English, there are four skill that should be mastered by the students. They are listening, speaking, reading and writing. These skills always become the target or final learning objectives. In other words, the four-language skills application of the knowledge of language that the learners get during the process. Reading is one of important aspects in learning English. Reading itself is complex application process because it involves the internal and external factors of students. The internal factors are everything from the students which can be thought, as a result of an interaction in reading process and external factors are all the factors from outside of the students, (Bonwell, 1991:72).

Reading is an active process of identifying important ideas, comparing, evaluating and applying them. Therefore, in reading paragraph we have to try to comprehend the main ideas of the reading. Without comprehending the paragraph, it will be very difficult to understand what we have read or what the writer means in reading material (Mattis in Lamuhiddin, 1988:4). 
Based on many facts that in learning and teaching process, most of the students do not read so they have less reading ability. According to one of the information, the researcher had got the real fact of the school in SMA Negeri 18 Makassar. The researcher had got the information from the English teacher. Which in fact that students of class X 3 have average value of English only 5.0, and their less in English dominate in reading comprehension. So in this case the researcher takes the strategy to improve their reading comprehension especially in interpretative reading and literal reading. 7.00 as a score target and the students have to achieve the score target. If they do not achieve the target yet, so the researcher has to continue the process until the students achieve the score target. In this case the researcher has found the best strategy to improve the students' reading comprehension through Know-Want-Learn Strategy.

\section{PROBLEM STATEMENT}

1. How is the students' literal reading skill in their reading comprehension improve through Know-Want-Learn Strategy at SMA Negeri 18 Makassar?

2. How is the students' interpretative reading skill in their reading comprehension improve through Know-Want-Learn Strategy at SMA Negeri 18 Makassar?

\section{OBJECTIVE OF THE STUDY}

1. To explain the improvement of the students' literal reading skill in their reading comprehension through Know-Want-Learn Strategy at SMA Negeri 18 Makassar.

2. To explain the improvement of the students' interpretative reading skill in their reading comprehension through Know-Want-Learn Strategy at SMA Negeri 18 Makassar.

\section{SIGNIFICANCE OF THE STUDY}

The result of this study is expected to be useful information to the students and the teachers about possitive effect of the Know-Want-Learn (KWL) Strategy. So they will know and get in learning language not only from one method, but 
also from other as basic in teaching process especially to improving the students' reading comprehension.

The research will be limited to the use of Know-Want-Learn (KWL) Strategy to improve reading comprehension focused on literal reading skill which consist of the facts in the text, and then interpretative reading skill which consist of re-arranging the ideas or topic, explaining the authors' purpose of writing and conclusion of the text. Here the students are hoped to be able to answer the question according to the text.

\section{KNOW WANT LEARN (KWL) STRATEGY}

Developed by D. Ogle, ( $1986: 7$ ), KWL is an instructional scheme that develops active reading of expository texts by activating learners' background knowledge ( Bos \& Vaughn, 2002:147 ). It provides a structure for recalling what learners know about a topic, noting what they want to know, and finally listing what has been learned and is yet to be learned. Learners begin by brainstorming everything they Know about the topic. The relevant information is recorded in the K column of the KWL scheme. Learners then generate a list of questions about what they Want to know about the topic. These questions are listed in the $\mathrm{W}$ column. During or after reading, learners answer these questions. What they have Learned is recorded in the L column.

Carr \& Ogle in Omar, (2010:110) explain that KWL strategy is a set of well-organized steps to be followed by a student to attain reading comprehension. It is composed of three-columned map to be drawn on the board. The first column represents what the student knows about the topic. The second represents what the student wants to know in the text. The third represents what the student has learned after having read the text.

The K-W-L strategy is a method devised to teach students to read actively by engaging previous knowledge, asking questions, and recalling important information in the text to enhance comprehension. In the $\mathrm{K}-\mathrm{W}-\mathrm{L}$ strategy, the students are asked to list what they know about the subject and the questions they may have about the subject before reading the text selection. Then after reading the selection, the students are asked to write what they have learned about the 
subject. This strategy prompts the students to identify previous knowledge, to consider what they want or need to know and list the useful information learned from the selection during reading. This strategy expects the students to evaluate what they know and learn. The student may take the information learned in the selection and use it in a concept map or outline or as a summary of the selection. This strategy promotes active learning through reading, writing, discussing and/or problem solving. Research shows that active learning strategies like K-W-L lead students to engage in higher-order thinking such as analysis, synthesis and evaluation (Bonwell \& Eison, 1991:138).

Sampson (2002:528) affirms the success of the K-W-L method because it activates students prior knowledge and help them set a purpose for reading and recording what they learned. Using the K-W-L chart as an instructional strategy can help students actively read expository text for information, as well as interest and additional research about the topic. The K-W-L Method is an important comprehension strategy and can be accommodated for any learning level or grade in elementary schools.

According to Tierney and Readence (2000:121), "K-W-L represent a thoughtfully developed framework that appears to support students initiated learning", as it improves their reading, increase their motivation, their communication skills and their abilities to construct meaning from different texts. The KWL strategy is an instructional reading strategy that is based on moving from one stage to another. In the K stage: What I know, students access their background knowledge to the text they are reading by listing what they already know about a specific topic. Then in the $\mathrm{W}$ stage: What I want to know, students list what they want to know about the same topic, and finally, they summarize what they have leant in the L stage: What I have learnt (Peregoy \& Boyle, 2001:233).

Ogle (1986:167) states that the important of using the KWL strategy in some Points as follows:

a. Help students to be active thinkers while they read giving them specific things to look for and having them reflect on what they learned when they are finished reading. 
b. Help activate background knowledge and provide an opportunity for students to set their own learning objectives.

c. Encourages students to be more motivated and active as readers.

d. Can help students to ask effective question as they read and respond to the text.

e. To guide and monitor students learning and promote higher level thinking in their students.

f. To help students in understanding how the KWL work as an important component of comprehension text.

According to Ogle (1986:170) that the advantages of using KWL Strategy as follows:

a. Empower students to think about the text they are reading.

b. It inspires them to think creatively.

c. Encourages students to be a strategic reading while answering the questions.

d. Excellent for compiling data collaboratively.

e. Incorporates prior knowledge of learners.

Buehl (2001:94) states that the way in using the KWL strategy as follows:

Introduce the KWL strategy in conjunction with a new topic or text. Explain that the KWL worksheet will help them generate questions and focus their reading of the text.

Before you begin reading, pick a main concept from a text or supplementary text and ask the students to brainstorm what they already know about this topic. Have the students record their ideas and the ideas of classmates on their KWL papers and also record them on an overhead or chalkboard for students to follow along.

a. Brainstorm a list of student questions by asking "What are you most interested in learning about?"

b. When preparing to read, have the students use their knowledge and their questions to make predictions about the organization of the text, namely what major categories of information the author is apt to focus on. 
c. Read the text individually, in small groups, or as a class to answer the questions.

\section{READING COMPREHENSION}

Armbruster \& Osborn in Priyono (2010:25) define reading as an active cognitive process of interaction with print and monitoring comprehension to establish meaning. Then, Linbuln in Lamuhidin (1988:5) defines reading as a meaningful interpretation of printing or writing verbal symbols. It also explains that reading is one way in communicating with other people and also by self. Based on the some definition above, the researcher takes conclusion that reading is process of communicating with other people or by self in understanding the writer message.

Karolina (2006:8) explains that comprehension are skill development, visual act, a successive series of the eye movements, fixation, and regressions, perceptual act, the recognition word and assigning to is meaning that based on past experience, a reflection of cultural background, thinking process, information processing, and associational learning. Smith in Lamuhidin (1988:33) states that comprehension involved understanding the vocabulary, seeing the relationship among that words and concepts, organizing ideas, recognizing the author purpose, making judgment, and evaluating. Comprehension is essential in using reference materials. The comprehension in reading means that the child can accept the materials through ideas, emotion, plan or actions. The reader must to know the analysis procedure in comprehending what they read. Davis in Arif (2006:11) identifies eight comprehension skills through a factor analysis procedure, they are:

1. Recalling word meaning.

2. Drawing inference about the meaning of word from context.

3. Finding answers to question answer explicitly or merely in paraphrase of the context.

4. Weaving together ideas in the context.

5. Drawing inferences from the content.

6. Recognizing writer's purpose, attitude, tone, and mood.

7. Identifying writer's technique. 
8. Following the structure of a passage.

Thus, reading with comprehension refers to the students' understanding about what they read. Reading comprehension refers to reading with comprehension. Lamuhidin (1988:11) defines that reading comprehension is understood what has been read.

Based on the some definition above, the researcher concluded that reading comprehension is ability in understanding, evaluating of information and ideas that has been read through interaction between author and reader. The achievement in reading comprehension is based on how far a reader can comprehend and gain meaningful information enclosed by the author reading achievement that can be gained toward reading skills and reading competence. Besides, good reading strategy also treats as a requirement.

\section{CONCEPTUAL FRAMEWORK}

The conceptual framework that will be the basic from this research and can be visualized in figure below. The figure shows the activity process of the teaching and learning of English in reading skill through reflection learning. The components of figure are described as follows: 


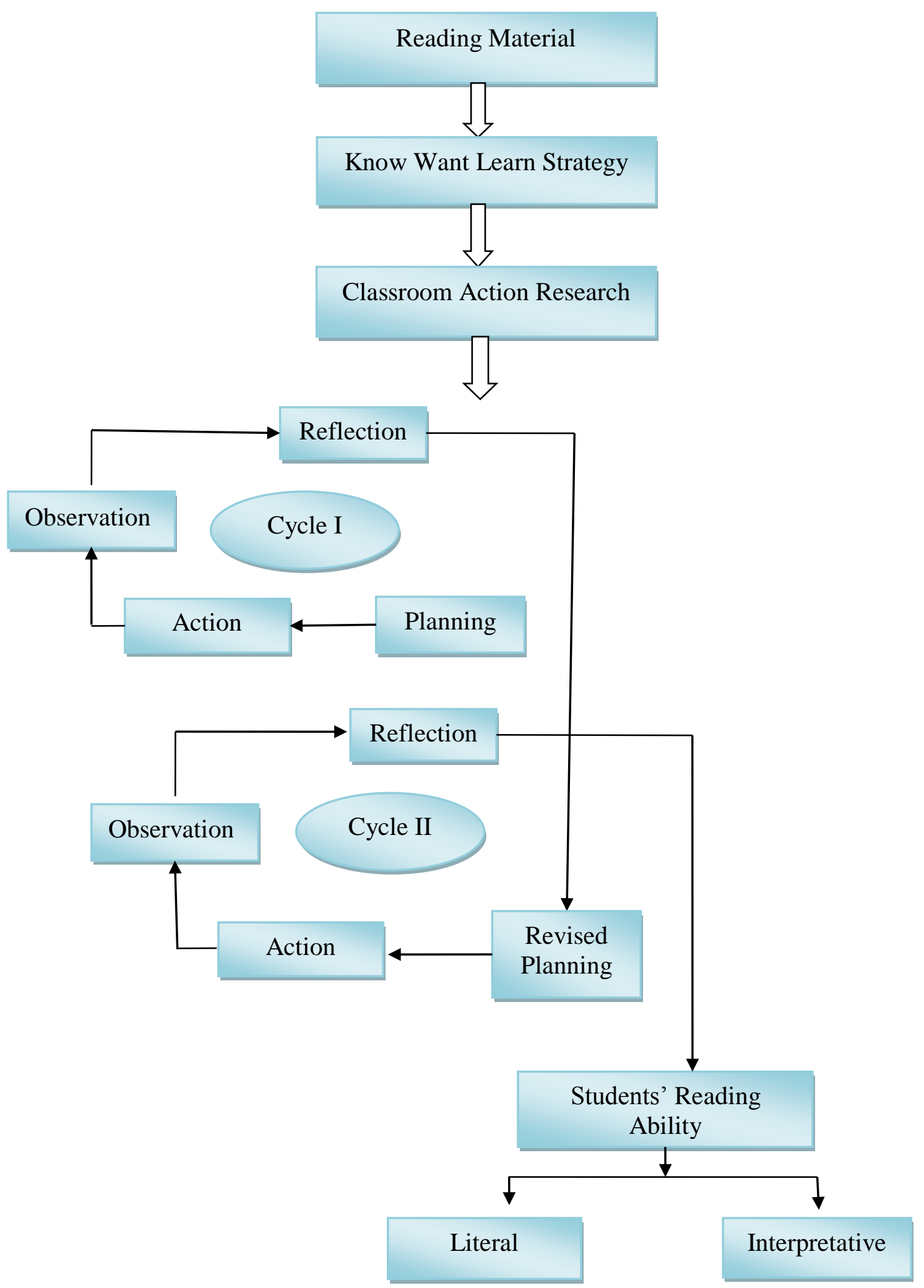

There are two variables that are briefly classified; they refer to reading comprehension, namely literal reading and interpretative reading skills. Teaching 
and learning refers to the used to teaching reading comprehension namely Know Want Learn and refers to the students' achievement on reading comprehension.

\section{RESEARCH METHOD}

This research followed the principal working of Classroom Action Research (CAR) that contained of four stages; they are: Planning, Implementation of Action, Observation, and Reflection. This research held around two cycles. Those were first and second cycle and each cycle is the series of activities which have a closed relation. Where, the realization of the second cycle was continued and repaired from the first cycle.

In this classroom Action Research (CAR), the observer used CAR principle to collected the data. The research consisted of two cycles with each cycle consisted of four phases.

\section{Cycle I}

\section{The Planning}

The activities would be in this stage as follows:

a. Studying and understanding the material that would be taught.

b. Making the lesson plan for the implementation of the action.

c. Making the sheet for observation to seen the condition of teaching and learning process when it was being continued.

d. Making the sheet of students' assessment, to measured the students' ability in reading.

\section{Implementation of Action}

The steps were as follows:

a. The teacher made informal greeting and self introduction. Then, told the students about the learning and why it was important.

b. Introduction the strategy by giving students written and verbal description.

c. Teachers activated students' prior knowledge by asking them what they already know.

d. The students (collaborating as a classroom unit or within small groups) set goals specifying what they want to learn.

e. After reading students discussed what they have learned. 
f. Students apply higher-order thinking strategies which helped them construct meaning from what they readed and helped them monitor their progress toward their goals. A worksheet is given to every student that included column for each of these activities.

\section{Observation}
a. The situation of teaching and learning activity.
b. Students' competence in applying Know-Want-Learn Strategy.
c. Students' participation and activeness.

\section{Reflection}

The result of evaluating analyze would be reflected to the cycle II. The researcher analyzed first cycle to knew whether the action of its cycle research successed criteria based on the test result of the first action. Everything less in cycle I, the researcher would continued to the cycle II and would be completed in cycle II, and also the complete things in cycle I would be more improved into the next cycle.

\section{Cycle II}

This cycle was the continuity from the cycle one. Here, researcher improved the weakness from the cycle one.

\section{The Planning}

The activity would be in this stage as follows:

a. Continuing the activities that have been done in first cycle.

b. Repairing the weakness in the first cycle.

c. Making planning again in the scenario earning process from the result of cycle I reflection.

d. Action research repaired.

\section{Action}

In this stage, action was done to improved the result based on the cycle reflection I. There were several steps in reading comprehension by using KWL strategy, those were:

a. Teacher developed their instruction around certain component that help students found the connection and helped them comprehend. 
b. Students also can learned about how the writers wrote about certain themes, topics or issues.

c. Students can usually found a topic they can enjoy from an author.

d. Teacher can share their own questions they may have when students were reading.

e. Students can made list a question and the class is discussing the reading.

f. Teacher seems to focused on questions that quiz the students to see what they know about a topic.

\section{Observation}

Observation was collecting data activity related with the learning English process which has solving problem and learning strategy. So, in this stage the researcher asked the students to collected their final reading, to measured the students' ability after implementing the Know-WantLearn Strategy.

\section{Reflection}

According to the achieved result of the observation that been collected and analyzed. From the result of the researcher, the researcher can draw conclusion that Know-Want-Learn can improve the students' reading comprehension.

\section{RESEARCH VARIABLES AND INDICATORS}

This research used two variables, they were:

1. Independent Variable

The independent variable was Know-Want-Learn Strategy. It was as the strategy used by the research when teaching the material.

2. Dependent Variable

Dependent variable was the students' reading comprehension especially in interpretative reading and critical reading with the indicators as follows:

a. Indicators of literal reading were the fact of the text, location and times. 
b. Indicators of interpretative reading were the rearrangement of the ideas or topic, explained the authors' purpose of writing and conclusion of the text.

\section{RESEARCH SUBJECT \& INSTRUMENT}

The research subjects in this research were the students of class $\mathrm{X} 3$ at SMA Negeri 18 Makassar which consisted of 32 students. In this research instrument the writer used reading test that consist of ten items all of the item are essay test. The teacher gave test in each cycle to found out the improvement of the students' reading comprehension.

In this Classroom Action Research, the researcher used some instruments. They are test and observation sheet.

1. Test

It is designed to measure the students' ability in English reading in each cycle. The test format was test to made the three column consist of Know, Want, and Learn. Then the students wrote in the column before, after and during reading.

\section{Observation Sheet}

It is used to observe and to record the students' activities during the teaching and learning process for each cycle in applying Know-Want-Learn Strategy. The format of the observation sheet was checklist format whether the students were actively participated or not.

\section{B. PROCEDURE OF DATA COLLECTION}

To collect the data was done with the following procedure:

1. The researcher used observation sheet to find out the students' participant in teaching learning process through KWL Strategy. It would be done in every cycle. It was sum at the end of cycle one and two.

2. The researcher gave test to students to found out their improvement of students in reading comprehension by using KWL Strategy.

Researcher gave test to students by following the step below:

a. Researcher prepared test material or topic for students. 
b. Researcher asked students to follow all rules in KWL Strategy to improved reading comprehension and gave correction to their mistakes.

\section{TECHNIQUE OF DATA ANALYSIS}

1. Found out the mean score of the students' achievement in reading through Know-Want-Learn by using the following formula :

$$
\begin{aligned}
& \bar{X}=\frac{\sum \mathrm{x}}{\mathrm{N}} \\
\bar{X} & =\text { Mean score } \\
\sum \mathrm{X} & =\text { Total score } \\
\mathrm{N} & =\text { The total number of student (Gay, 1981:298). }
\end{aligned}
$$

2. To knew the students' participant in teaching learning process through KnowWant-Learn Strategy, researcher used percentage formula as follows:

$$
\begin{aligned}
& \mathrm{P}=\underline{\mathrm{FQ}} \times 100 \\
& 4 \times \mathrm{N} \\
& \mathrm{P}=\text { Percentage } \\
& \text { FQ }=\text { Sum of all the student's score } \\
& \mathrm{N} \quad=\text { Total students, (Sudjana, 1990:36). }
\end{aligned}
$$

3. To analyzed the percentage strategy by using this formula:

$$
\begin{aligned}
& \mathbf{P}=\frac{\boldsymbol{F}}{\boldsymbol{N}} \boldsymbol{x} \mathbf{1 0 0} \\
\mathrm{P} & =\text { Percentage rate } \\
\mathrm{F} & =\text { Frequency } \\
\mathrm{N} & =\text { The total number of student (Sudjana in Karolina, 1999:2008). }
\end{aligned}
$$

The data got from cycle I and cycle II is analyzed through the following steps:

$96-100$ is classify as excellent

$86-95$ is classify as very good

$76-85$ is classify as good

$66-75$ is classify as fair

$65-0$ is classify as poor (Depdikbud in Samsah, 1981:2008). 


\section{FINDINGS AND DISCUSSIONS}

This chapter particularly presents the findings of the research cover with the description of the students' improvement in literal and interpretative reading. In the discussion part, the writer described the findings in detail.

The result of the students' Reading Comprehension in teaching and learning process toward the application of Know-Want-Learn Strategy in improving the students' reading comprehension at the first grade in class X3 of SMA Negeri 18 Makassar which is conducted in 2 cycles during 8 meetings is taken by the observer through test sheet. It can be seen clearly through the following table:

Table 1: Result Improvement of the Students' Reading Comprehension

\begin{tabular}{|l||l|l|l||l|l|}
\hline \hline \multirow{2}{*}{$\begin{array}{l}\text { Literal } \\
\text { Interpretative }\end{array}$} & \multicolumn{2}{|l|}{ Mean Score } & \multicolumn{2}{|l|}{ Percentage Improvement } \\
\cline { 2 - 6 } & D-Test & Cycle I & Cycle II & D-Test to C I & C I to C II \\
\hline $\begin{array}{l}\text { Reading } \\
\text { Comprehension }\end{array}$ & 54,07 & 69,07 & 73,81 & $39,47 \%$ & $12,47 \%$ \\
\hline \multicolumn{2}{|l|l|l|}{ Research findings above indicate there is improvement of students' } \\
\hline
\end{tabular}
reading comprehension through Know-Want-Learn Strategy from D-Test>Cycle I> Cycle II with mean score achievement of students in D-Test is 54.07, Cycle I that is 69.07 , and after conducted Cycle II mean score of students improvement become 73.81. There is also significant improvement of the students' reading comprehension from Cycle I to Cycle II where percentage improvement of the students' reading comprehension from D-Test to Cycle I is $39.47 \%$ while from Cycle I to Cycle II is $12.47 \%$.

Research findings above also showing an achievement of students in reading comprehension because the student was reaching standard minimum of efficacy that is $70 \%$ and standard mean score 70.01 . Therefore, researcher was concluding that students' reading comprehension was complete and success toward the used Know-Want-Learn Strategy.

\section{Scoring Classification}


It has been mentioned in the previous chapter that after tabulating and analyzing the students' scores into percentage, then they were classified into five levels based on Depdikbud classification as can be seen in the following tables:

Table 2: Frequency and Rate Percentage of the Students' Reading Comprehension

\begin{tabular}{|c|c|c|c|c|c|c|c|c|}
\hline \multirow[t]{3}{*}{ No } & \multirow[t]{3}{*}{ Classification } & \multirow[t]{3}{*}{ Range } & \multirow{2}{*}{\multicolumn{2}{|c|}{$\begin{array}{l}\text { Non K-W-L } \\
\text { Strategy } \\
\text { D-Test }\end{array}$}} & \multicolumn{4}{|c|}{$\begin{array}{l}\text { The Application of } \mathrm{K}-\mathrm{W}-\mathrm{L} \text { in } \\
\text { Reading Comprehension }\end{array}$} \\
\hline & & & & & \multicolumn{2}{|c|}{ Cycle I } & \multicolumn{2}{|c|}{$\overline{\text { Cycle II }}$} \\
\hline & & & Freq & $\%$ & Freq & $\%$ & Freq & $\%$ \\
\hline 1 & Excellent & $96-100$ & 0 & 0 & 0 & 0 & 0 & 0 \\
\hline 2 & Very Good & $86-95$ & 0 & 0 & 0 & 0 & 3 & 7.89 \\
\hline 3 & Good & $76-85$ & 1 & 2.63 & 2 & 5.26 & 5 & 13.15 \\
\hline 4 & Fair & $66-75$ & 3 & 7.89 & 21 & 55.26 & 30 & 78.94 \\
\hline 5 & Poor & $65-0$ & 34 & 89.47 & 15 & 39.47 & 0 & 0 \\
\hline \multicolumn{3}{|c|}{ Total } & 38 & 100 & 38 & 100 & 38 & 100 \\
\hline
\end{tabular}

Table above explaining about Frequency and Rate Percentage of the Students' Reading Comprehension and result of table above showing in D-Test there were only 1 students $(2.63 \%)$ got score in good classification, 3 students $(7.89 \%)$ got score in fair classification, and 34 students $(89.47 \%)$ got score in poor classification.

In Cycle I score of students was improving. There were 2 students $(5,26 \%)$ classified as good, 21 students $(55,26 \%)$ classified as fair, and 15 students $(39,47 \%)$ classified as poor.

Then in the Cycle II, the score of students more improvement than Cycle I there were 3 students $(7,89 \%)$ got result in very good classification, 5 students $(13,15 \%)$ got result in good classification, 30 students $(78,94 \%)$ classified as fair, and no students classified as poor.

Table frequency and rate percentage of the students' reading comprehension above supported that there was improvement of the students' reading comprehension through Know-Want-Learn Strategy at the first grade in class X3 of SMA Negeri 18 Makassar from the D-Test to Cycle I and Cycle I to Cycle II. 
Table 3: Result of Students' Activity in Learning Process through KnowWant-Learn Strategy

\begin{tabular}{||l|l|l|l||l|l||}
\hline \multirow{2}{*}{ No } & \multirow{2}{*}{ Cycle } & \multicolumn{4}{|l|}{ Improvement of Students' Activity } \\
\cline { 3 - 6 } & & I & II & III & IV \\
\hline 1. & I & $45.39 \%$ & $51.3 \%$ & $50.65 \%$ & $67.10 \%$ \\
\hline 2. & II & $64.47 \%$ & $75 \%$ & $72.36 \%$ & $90.78 \%$ \\
\hline
\end{tabular}

Research findings above showing that result improvement of students' activity in learning process have been complete after students' activity assessment reached standard of efficacy (70\%). The table above showed the result improvement in Cycle I that is $45.39 \%$ in the first meeting and the fourth meeting improved $67.10 \%$. Then the Cycle II in the first meeting $64.47 \%$ and improved become $90.78 \%$ the fourth meeting. To clearly it can be seen diagram 3 for result improvement of students' activity as follows;

Then at the Cycle II activeness of students is more improvement than cycle I. Here result improvement of students' activity in the first meeting $64.47 \%$ students active, second meeting $75 \%$, the third meeting $72.36 \%$ and the fourth meeting, activity of students assessed improvement become $90.78 \%$. This result indicated that students were like with applied Know-Want-Learn Strategy in learning process.

\section{DISCUSSION}

After analyzing data with indicators of research is to find out the students reading comprehension and find out the students' activity in learning process through Know-Want-Learn Strategy. Every Cycle conducted with four meetings and one meeting was evaluation process. Standard achievement minimum of students that was mean percentage $70 \%$ and standard minimum of mean score that was 70.01 .

In this part, discussion deals with the interpretation of the findings derived from the result of statistical analysis and the researcher's notes during the classroom interaction. The description of the data collected through reading comprehension test as explained in the previous section shows that the students' reading comprehension improved. It was proved by the frequency and the rate percentage of the students' score in D-Test, Cycle I, and Cycle II. 


\section{Diagnostic Test (D-Test)}

Before conducting a classroom action research in class X3 of SMA Negeri 18 Makassar researcher collected data through diagnostic test to measure the students' prior knowledge in English Learning. After giving D-Test, the researcher found that the students' reading comprehension at the first grade in class X3 of SMA Negeri 18 Makassar was low, this matter proved that D-Test there were only 1 students $(2.63 \%)$ got score in good classification, 3 students (7.89\%) got score in fair classification, and 34 students $(89.47 \%)$ got score in poor classification.

\section{The Students' Reading Comprehension}

Based on the result D-Test above made the researcher conducted classroom action research with used Know-Want-Learn Strategy to improving students' reading comprehension. Action research here consisted of 2 cycles and every cycle consisted of 4 meetings and 1 meeting is evaluation process. Each cycle in research consisted of 4 phases namely: planning, action, observation, and reflecting.

The indicator of improving students' reading comprehension that is how is the students' making conclusion (literal) and how the students' found the main idea of the text (interpretative).

After researcher conducted research with used Know-Want-Learn Strategy in Cycle I got result mean score of students that is 69.07 and Cycle II mean score of students' reading comprehension improvement become 73.81, while percentage improvement from D-Test to Cycle I is $39.47 \%$ and from Cycle I to Cycle II is $12.47 \%$. Based on the research findings mean score and percentage improvement of student, researcher concluded that students' reading comprehension was success and complete in Cycle II. This matter indicated that applied Know-WantLearn Strategy in improving students' reading comprehension is effectively and good at using in learning process.

\section{The Students' Activity in Learning Process}


Observation of students' activity conducted during learning process, all of data collected written on observation sheet. Later, assessment component of students' activity in learning process;

1. Students focus on lesson/ attention when the teacher or researcher explains the lesson.

2. Students asked to the teacher during learning process.

3. Students answered the questions from teacher during learning process.

4. Students found the main idea about the task.

5. Students made conclusion by self about task.

Result improvement of students' activity in Cycle I that is the first meeting $45.39 \%$ students assessed active in class, second meeting $51.31 \%$, the third meeting $50.65 \%$ and fourth meeting improve and higher than Cycle $I$ that is $67,10 \%$. This matter assessed no yet reached target efficacy that is $70 \%$. Therefore, researcher needed to do stabilization in the Cycle I and before to Cycle II researcher have to conducted reflection.

In phase of reflection researcher found that a lot of students less be active in some cases such as, less given attention during the teacher explained material, didn't confidence and shy to enquire to teacher and less active. This matter was having an effect to improvement of students' reading comprehension; as a result students' reading comprehension still low and far from expected result. Therefore researcher done reflection before continues to Cycle II. Following the result of reflection by researcher:

1. Remain to used the way of Cycle one

2. Given motivation to students so that they will more active in teaching process.

3. Built self confidence of student with given approach and guided individually to lessen shies of students so that students don't scare for ask to teacher about their difficulty.

4. Explained about purpose of lesson.

5. Increased cooperate with friends so students could share knowledge with their friend. 
After researcher found problem solved in reflection, researcher continues to Cycle II and the result of Cycle II that is activeness of students is more improvement and higher than Cycle I. Here result improvement of students' activity that is at the first meeting found $64.47 \%$ students active, second meeting $75 \%$, and the third meeting students improvement become $90.78 \%$. This matter indicated that students more active in learning process toward applied KnowWant-Learn Strategy.

\section{BIBLIOGRAPHY}

Armbruster, B. Lehr, F \& Osborn, J. 2001. Put Reading First: The Research Building Block for Teaching Children to Read. Washington, Dc: The U.S.

Brewton. 1962. Teaching Reading in the Content Areas. mcRel, Colorado.

Bonwell, C. \& Eison, J. (1991). Active learning: Creating excitement in the classroom. ERIC Digest. Available. Retrieved from http://www.ed.gov/databases/ERIC_Digests/ed340272.html. On July 29 2012.

Bos, C.S \& Vaughun, S. 2002. Strategies for Teaching Students with Learning and Behavior Problem. Boston: Allyn and Bacon Retrieved from http://www.answers.com/or http://answers.yahoo.com.On 24 $4^{\text {th }}$ August 2012.

Buehl, D. 2001. Classroom Strategies for Interactive Learning. Second edition: Network, Delaware, International Reading Association.

Carr, E. \& Ogle, D. 1987. K-W-L plus: A strategy for comprehension and summarization. Journal of Reading.

Gay. L, R. 1981. Education Research: Competencies for Analysis and Applicant. Columbus : A Bell and Howell Company, Charles, E. Merril Publishing Co.

Frederiksen, 1981. An Introduction to Language. New York: Havfix.

Karolina, Intan. 2006. Increasing the Students Reading Comprehension through Know Want Plus Method. Thesis: UNESA Surabaya.

Lamuhiddin, 1988. Correlation between Vocabulary Command and Reading Comprehension of the second year students of SMA Negeri 3 UP. Thesis: FPBS IKIP UP. 
Maryam. 2007. Learning Cooperative Reading through the Narrative towards the Contextual Meaning (A Study of Comprehension View). Thesis: Unismuh Makassar.

Mattis, K. 2005. Reading Comprehension. New Jersey: Person education, inc.

Ogle, D.M. 1986. A teaching Model Develops Active Reading of Expository Text. Retrieved From http://www.indiana.edu/ 1517/KWL. on 25 ${ }^{\text {th }}$ August 2012. Omar, Salim. 2010. The Impact of Using KWL Strategy on Grade Ten Female Students' Reading Comprehension of Religious Concepts in Ma'an City. Thesis: University of Al Husein Bin Talal, Jordan.

Peregoy, S. \& Boyle, O. (2001). Reading, writing \& learning in ESL. New York: Addision Wesley Longman.

Priyono. 2010. Improving Students' Reading Comprehension Through A Kwl Strategy. Thesis: UNS Surakarta.

Sampson, M. (2002, March). Confirming a k-w-l: Considering the source. Reading Teacher, 55(6), 528-532. Academic Search Complete database. Retrieved from July 15, 2012.

Tierney, R. \& Readence, J. (2000). Reading strategies and practices. Boston: Allyn \& Bacon. 